\title{
KERANGKA REGULASI TATA KELOLA LEMBAGA MENAJEMEN \\ KOLEKTIF: SUATU PERBANDINGAN
}

\author{
Yoyo Arifardhani \\ Email : arifardhaniyoyo@gmail.com
}

\begin{abstract}
Abstrak
Pencipta dapat mengoptimalkan implementasi hak ekonomi atas karya ciptanya melalui lembaga manajemen kolektif yang membuat pencipta dan pemegang hak cipta serta pengguna dapat mengakses biaya transaksi yang lebih rendah sehingga dapat meningkatkan jumlah hak-hak cipta yang dapat diperdagangkan. Namun di sisi yang lain, sifat monopolistik lembaga manajeman kolektif berpotensi disalahgunakan sehingga diperlukakan kerangka regulasi tata kelola yang baik bagi lembaga manajemen kolektif. Kerangka regulasi terkait pengaturan, pengawasan, tata kelola, dan implementasi fungsi sosial dan budaya lembaga manajemen kolektif di negara-negara Eropa dapat menjadi rujukan pembaharuan hukum pengelolaan lembaga manajemen kolektif di Indonesia.
\end{abstract}

Kata Kunci: Hak Cipta, Lembaga Manajemen Kolektif, Perbandingan Hukum 


\section{PENDAHULUAN}

Hak cipta adalah hak eksklusif atau yang hanya dimiliki si pencipta atau pemegang hak cipta untuk mengatur penggunaan hasil karya atau hasil olah gagasan atau informasi tertentu di bidang sastra, seni, musik dan ilmu pengetahuan. Pada dasarnya, hak cipta merupakan hak untuk menyalin suatu ciptaan atau hak untuk menikmati suatu karya. Hak cipta juga sekaligus memungkinkan pemilik dan pemegang hak tersebut untuk membatasi pemanfaatan, dan mencegah pemanfaatan secara tidak sah atas suatu ciptaan.

Perlunya perlindungan hak cipta adalah sama ketika kita membicarakan justifikasi perlindungan kekayaan intelektual pada umumnya, yang salah satu teori utamanya mendasarkan pada pendekatan insentif (incentive theory). Teori insentif mengutamakan pada keberlanjutan suatu ciptaan. Dengan diberikannya insentif bagi seorang pencipta, hal ini akan memberikan dorongan kepada pencipta untuk menghasilkan karya lebih banyak dan lebih baik lagi. Dengan kata lain, insentif merupakan pemicu semangat bagi seorang pencipta untuk menciptakan karya cipta yang lebih dari sebelumnya ${ }^{1}$. Insentif ini tidak ada artinya jika pencipta tidak dapat secara optimal menikmati hasil ciptaan secara ekonomis dengan optimal. Pencipta, terutama pencipta indvidu, tidak mungkin bisa berada di beberapa tempat yang sama (di beberapa tempat pertunjukan, restoran, diskotik atau karaoke) pada waktu bersamaan di seluruh Indonesia untuk menarik royalti dari pengguna (user) terhadap penggunaan karya ciptanya. ${ }^{2}$ Oleh karena itulah diperlukan suatu lembaga perantara yang mengelola hak ekonomi pencipta, yang di Indonesia disebut dengan lembaga manajemen kolektif.

\footnotetext{
${ }^{1}$ Robert M. Sherwood, Intellectual Property and Economic Development, Alexandria, Virginia, 1990, h. 38.

${ }^{2}$ Dalam kasus musik/lagu, pencipta atau pemegang hak cipta disini termasuk pencipta lagu, komposer musik, penerbit musik (music publisher, yang diberi mandat oleh pencipta/komposer untuk mengelola hak komersial mereka, artis pelaku pertunjukan,) dan perusahaan rekaman (record company). Pengguna hak dalam hal ini adalah broadcaster (televisi dan radio), perusahaan rekaman (untuk hak mekanikal), penyedia jasa internet, perusahaan telekomunikasi, manufaktur elektronik dan komputer untuk konsumen (dalam hal private copying), restoran, tempat umum, diskotik, salon rambut, dan lain-lain.
} 
Lembaga manajemen kolektif atau collective management organization (CMO) adalah organisasi yang mengelola hak ekonomi atas suatu ciptaan, seperti lagu, musik, buku dan film, dan atau hak terkait seperti karya pertunjukan, karya rekaman, karya siaran, untuk mewakili dan atas nama pemegang hak. UndangUndang Nomor 28 Tahun 2014 Tentang Hak Cipta (“UU Hak Cipta 2014”), Pasal 1 butir 22 memberikan definisi Lembaga Manajemen Kolektif sebagai institusi yang berbentuk badan hukum nirlaba yang diberi kuasa oleh Pencipta, Pemegang Hak Cipta, dan/atau pemilik hak terkait guna mengelola hak ekonominya dalam bentuk menghimpun dan mendistribusikan royalti.

Sebagaimana telah disinggung bahwa pencipta memiliki hak ekonomi untuk melakukan pemanfaatan atas ciptaannya, namun dalam rangka pengelolaan hak cipta tersebut atau dalam rangka mengambil keutungan atau royalti tidak memungkinkan untuk dilakukan sendiri. Keberadaan lembaga manajemen kolektif sangat membantu pencipta atau pemegang hak cipta dalam mendapatkan keuntungan atas komersialisasi ciptaannya.

Dengan demikian, keberadaan keberadaan lembaga manajemen kolektif memiliki arti penting, yaitu dalam hal sebagai berikut ${ }^{3}$ :

1. Menghasilkan karya

Komposer, penulis, musisi, penyanyi, pelaku dan talenta lainnya yang terdapat pada seseorang dan memiliki nilai sangat berharga di masyarakat akan terus berkarya untuk menghasilkan yang terbaik.

2. Memberikan insentif

Untuk memberikan penghargaan atas hasil karya mereka dengan memberikan insentif sebagai imbalan upah yang telah memberikan izin untuk menggunakan karya cipta mereka.

3. Mewakili kepentingan pencipta

Lembaga manajemen kolektif adalah penghubung antara pencipta dengan pengguna suatu karya cipta, seperti stasiun radio. Lembaga manajemen kolektif

${ }_{3}$ Agung Damarsasongko, Ketentuan Tentang Lembaga Manajemen Kolektif Dalam Undang-Undang No. 28 Tahun 2014 tentang Hak Cipta, Meida HKI, Direktorat Jenderal Kekayaan Intelektual, Kementerian Hukum dan HAM,hlm. 10.. 
menjamin bahwa pencipta dan pemegang hak cipta akan menerima pembayaran setelah karya cipta mereka digunakan oleh pihak lain.

Namun demikian, dalam praktiknya masih sering terjadi persengketaan atau permasalahan terkait pengelolaan royalti hak cipta, baik sengketa yang terjadi antara lembaga manajemen kolektif dengan pemilik hak cipta maupun antara lembaga manajemen kolektif dengan pengguna (user). Sebagai contoh kasus Ahmad Dhani dan Anang Hermansyah yang mencabut kuasa penarikan royalti yang dilakukan oleh Yayasan Karya Cipta Indonesia (YKCI). Menurut mereka YKCI tidak mampu mengemban tugasnya karena tidak transparan dalam perhitungan pembagian royalti. ${ }^{4}$ Kemudian sengketa antara YKCI dengan Persatuan Artis Musik Melayu Dangdut Indonesia (PAMMI). PAMMI, dibawah pimpinan Rhoma Irama, membentuk Royalti Anugrah Indonesia (RAI) sebagai wadah pemungut royalti khusus dangdut setelah kecewa dengan YKCI karena menganggap pembagian royalti yang terkesan seenaknya. ${ }^{5}$ Permasalahan pembagian royalti ini juga diamini oleh Glenn Fredly dimana menurutnya royalti yang selama ini didapatkan musisi terkait hasil karyanya masih belum transparan. ${ }^{6}$

Persengketaan yang terjadi sebagaimana dikemukakan di atas pada dasarnya secara langsung ataupun tidak langsung sangat berkaitan dengan tata kelola (governance) lembaga manajemen kolektif. Permasalahan dalam tata kelola, seperti permasalahan dalam aspek transparansi dapat berujung kepada persengketaan antara lembaga manajemen kolektif dengan pencipta atau dengan pengguna. Praktik tata kelola yang kurang baik ini dapat terjadi diakibatkan oleh pengaturan peraturan perundang-undangan terkait lembaga manajemen kolektif yang kurang memadai dan/atau tidak jelas. Oleh karena itu, tulisan ini membahas mengenai kerangka regulasi tata kelola lembaga manajemen kolektif.

\footnotetext{
4 Tempo.co, Anang dan Dhani Persoalkan Pembayaran Royalti YKCI, Rabu, 19 Maret 2014. https://seleb.tempo.co/read/563589/anang-dan-dhani-persoalkan-pembayaran-royaltiykci/full\&view=ok

${ }^{5}$ Poskota News, Kecewa dengan KCI Pencipta Dangdut Bentuk RAI, Jumat, 29 Maret, 2013, http://poskotanews.com/2013/03/29/kecewa-dengan-kci-pencipta-dangdut-bentuk-rai/

${ }^{6}$ Kumparan,5 Musisi yang Memperjuangkan Hak Royalti di Indonesia, 9 Maret, 2018. https://kumparan.com/@kumparanhits/5-musisi-yang-memperjuangkan-hak-royalti-di-indonesia
} 
Penelitian dalam tulisan ini menganalisis pengawasan dan tata kelolaa lembaga manajemen kolektif berusaha menjawab pertanyaan riset berupa apa manfaat lembaga manajemen kolektif dengan menggunakan pendekatan perbandingan hukum (comparative approach) di beberapa negara Eropa. Unsurunsur normatif penting dalam kerangka regulasi lembaga manajemen kolektif di berbagai negara akan dianalisis. Hasil analisis tersebut akan dibandingkan dengan dan sebagai bahan masukan terhadap kerangka regulasi lembaga manajemen kolektif di Indonesia. Pada tulisan ini, sepanjang tidak disebutkan lain, lebih memfokuskan pada pengelolaan hak cipta pada bidang musik/lagu.

Bab I berisi bagian pendahuluan. Bab 2 menerangkan secara umum mengenai pengelolaan lembaga manajemen kolektif. Bab 3 memaparkan perbandingan model tata kelola lembaga manajemen kolektif di negara Perancis, Jerman, Inggris dan Swedia dalam aspek pengaturan dan pengawasan, transparansi dan akuntabilitas serta fungsi sosial dan budaya. Bab 4 merupakan analisis regulasi lembaga manajemen kolektif Indonesia dilihat dari aspek-aspek perbandingan yang telah dikaji dalam Bab 4. Bab 5 merupakan rangkuman dan memberikan saran kerangka regulasi tata kelola lembaga manajemen kolektif di Indonesia.

\section{GAMBARAN UMUM PENGELOLAAN LEMBAGA MANAJEMEN KOLEKTIF}

Dari perspektif ekonomi lembaga manajemen kolektif berfungsi untuk mengatasi kegagalan pasar (market failure), dimana lembaga ini memiliki tiga fungsi yaitu: (a) Melisensi karya kepada pengguna (to license use); (b) Memonitor penggunaan karya (to monitor use), dan (c) Mengumpulkan dan mendistribusikan pendapatan kepada anggotanya (to collect and distribute revenue). ${ }^{7}$ Lembaga manajemen kolektif mengumpulkan pendapatan dari penggunaan sekunder yang nilainya rendah (low value) tetapi volumenya tinggi (high volume). Artinya biaya lisensi secara satuannya adalah kecil namun karena jumlah lisensi yang dikeluarkan

7 Morten Hviid, Simone Schroff, John Street, Regulating Collective Management Organisations by Competition: An Incomplete Answer to the Licensing Problem?, 7 (2016) JIPITEC 256 para 1. 
adalah banyak, hal ini menghasilkan aliran pendapatan yang substansial. Lembaga manajemen kolektif mengelola hak-hak dari pencipta yang merupakan anggotanya secara kolektif dengan menyediakan lisensi sepaket (blanket) kepada para pengguna. Dengan mengelola hak-hak tersebut secara kolektif, lembaga menajemen kolektif dapat menurunkan biaya transaksi serta menyediakan kerangka lisensi yang stabil. Dalam istilah ekonomi, lembaga ini membuat pasar berfungsi dengan memastikan keefektifan hak cipta dimana pemilik hak cipta tidak mungkin melakukan kontrak secara langsung. Lisensi blanket memberikan pengguna, terutama broadcasters, hak untuk menggunakan semua lagu musik yang terdapat dalam daftar (repartoire) lembaga manajemen kolektif. Keberadaan lisensi blanket menurunkan biaya transaksi karena ia tidak mempersyaratkan negosiasi dalam hal harga atau ukuran yang tepat dari sekumpulan hak-hak yang diikat untuk setiap transaksi.

Oleh karena itu, dapat dikatakan bahwa keberadaan lembaga manajemen kolektif memiliki manfaat dari segi praktis, ekonomis dan hukum, sebagaimana berikut ini ${ }^{8}$ :

1. Dari segi praktis, pencipta dan pemegang hak cipta tidak mungkin dapat berada di banyak tempat pada waktu yang sama untuk melaksanakan haknya, demikian pula pemilik hak cipta asing tidak mungkin melaksanakan haknya di luar negara asalnya, kecuali dengan biaya dan tingkat kesulitan yang sangat besar.

2. Secara ekonomis, adalah lebih murah untuk membagi beban biaya negosiasi, pengawasan, dan penarikan kepada sejumlah besar pencipta atau pemegang hak cipta.

3. Secara hukum, mekanisme manajemen kolektif memungkinkan pengguna mendapatkan ijin untuk menggunakan karya dalam jumlah besar secara efisien dan sah dari segi hukum.

${ }^{8}$ CISAC, The Importance of Collective Management, International Confederation of Societies of Authors and Composers, h. 3. 
Adapun beberapa teknik atau cara yang digunakan oleh lembaga manajemen kolektif dalam melakukan penarikan royalti dari pengguna (user) adalah sebagai berikut ${ }^{9}$ :

1. Traditional Collective Management Organisations, mewakili anggota organisasi (pencipta/pemegang hak cipta) untuk melakukan negosiasi atas harga dan syarat penggunaan, hak yang diberikan dalam lisensi, mengambil dan mendistribusikan royalti.

2. Rights Clearence Center, dimana pada sistem ini lembaga manajemen kolektif berperan sebagai agen dari pemilik hak untuk selalu mengingatkan penggunaan karya ciptanya karena pada sistem ini pencipta/pemegang hak cipta yang mengatur sendiri tentang syarat penggunaan hak cipta dan penentuan imbalannya.

3. One Stop Shops, adalah jenis penggabungan beberapa lembaga manajemen kolektif yang memberikan penawaran dan penarikan kepada pengguna atas sentralisasi sumber dimana hak akan diperoleh secara cepat dan mudah.

Dalam praktiknya, beberapa negara melakukan penarikan royalti kepada pengguna menggunakan sistem tradisonal dan one stop shops, atau di Inggris dikenal dengan sistem sentral. Metode penarikannya disesuaikan dengan kebutuhan dari lembaga manajemen kolektif tersebut. Sebagai contoh Performing Right Society for Music dan Phonographic Performance adalah lembaga manajemen kolektif yang bergerak di bidang musik namun masing-masing memiliki ruang lingkup yang berbeda-beda atas obyek penarikan royolti. Performing Right Society (PRS) adalah lembaga yang melakukan penarikan royalti untuk dua jenis hak atas karya cipta yaitu mechanical rights atau perbanyakan karya cipta dan hak atas pertunjukan. Sementara Phonographic Performance Ltd (PPL) melakukan penarikan royalti terhadap rekaman musik dan video musik untuk publik. Kedua lembaga tersebut masing-masing memiliki tarif dan metode penarikan yang berbeda satu sama lain sehingga pola penarikan royalti dapat dikatakan sebagai sistem tradisional. Namun dalam keadaan tertentu, PRS bekerja sama dengan PPL

${ }^{9}$ World Intellectual Property Organization, collective Management of Copyright and Related Right, WIPO Publication, No. L450CM/E. 
dalam melakukan penarikan dan pendistribusian royalti. Sebagai contoh ketika sebuah lagu diputar di stasiun radio BBC, maka PRS akan menarik royalti untuk atas nama pencipta lagu dan penerbit musik (music publisher) sedangkan PPL menarik royalti atas nama perusahaan rekaman yang merekam lagu tersebut. Contoh lainnya adalah The Copy Right Licensing Agency merupakan lembaga manajemen kolektif terhadap karya cipta berupa karya tulis yang mencakup buku, jurnal, dan majalah serta hasil-hasil cetakan lainnya. Penarikan royalti menggunakan sistem one stop shops.

Pencipta atau pemegang hak cipta memiliki hak untuk membatasi penggunaan karya ciptanya dan mendapatkan hak ekonomi atas penggunaan karya ciptanya. Terdapat beberapa hak-hak ekonomi yang dimiliki oleh pencipta atau pemegang hak cipta, hak-hak mana kemudian biasanya dikelola melalui lembaga manajemen kolektif. Jenis-jenis hak ekonomi pencipta dan pemegang hak cipta yang umumnya dikelola oleh lembaga manajemen kolektif antara lain adalah ${ }^{10}$ :

a. Hak pertunjukan di tempat umum (the right to public performance/performing right).

Contohnya musik yang diputar atau dimainkan di diskotik, restoran dan tempat umum lainnya. Jenis performing right terkait musik/lagu pada dasarnya dibagi menjadi dua jenis, yaitu small right untuk karya musik umum yang dikelola secara kolektif melalui lembaga manajemen kolektif, dan grand right, yang biasanya dikelola secara individu (biasanya adalah karya drama musikal). Dalam karya drama musikal, karena jumlah penggunaannya relatif kecil sehingga pengelolaan perijinannya dapat dilakukan secara langsung oleh pencipta. Sementara karya musik non-drama, penggunaanya jauh lebih sering dan dilakukan di berbagai banyak tempat, sehingga tidak praktis untuk dikelola secara individu.

${ }^{10}$ Lihat Mihaly Ficsor, Collective Management Of Copyright And Related Rights, WIPO, 2002, h. 37-94 dan Agung Damarsasongko, Ketentuan Tentang Lembaga Manajemen Kolektif Dalam Undang-Undang No. 28 Tahun 2014 tentang Hak Cipta, Meida HKI, Direktorat Jenderal Kekayaan Intelektual, Kementerian Hukum dan HAM,hlm. 10. 
b. Hak reproduksi mekanis dalam musik rekaman (the mechanical reproduction rights in recorded music)

Hak mekanikal adalah hak untuk mereproduksi karya dalam bentuk rekaman (fonogram atau fiksasi audiovisual) yang diproduksi "secara mekanis" dalam arti kata yang luas, termasuk prosedur elektro-akustik dan prosedur elektronik. Contohnya, reproduksi karya dalam CD, kaset, piringan hitam, atau bentuk lain dari rekaman.Tipikal hak mekanikal adalah hak komposer atas karya musik dan pencipta untuk merekam karya tersebut. Biasanya lembaga manajemen kolektif yang mengurus performing right juga mengelola mechanical right. Tetapi juga ada yang dipisah seperti AUSTRO-MECHANA di Austria atau NCB untuk negara-negara Nordik yang mengurus hak-hak pencipta dan penerbit musik. Harry Fox Agency di Amerika Serikat adalah lembaga yang mengurus untuk (music publisher). Walaupun terpisah kedua lembaga tersebut mempunyai hubungan dan aliansi yang erat, misalnya SACEM dan SDRM di Perancis, PRS dan MCPS di Inggris dan BUMA dan STE:MRA di Belanda.

c. Hak pertunjukan dalam karya-karya drama (the performing rights in dramatical works)

Pengelolaan hak atas karya drama biasanya tidak dilakukan dengan manajemen kolektif secara murni. Pengelolaannya lebih didasarkan pada prinsip agen, lembaga hanya menjadi perwakilan atau representatif dari pencipta karya drama. Tidak ada lembaga manajemen yang khusus mengelola hak karya drama, kecuali SACD di Perancis, Cara kerja lembaga ini adalah pencipta menginformasikan kepada lembaga manajemen kolektif. Kemudian lembaga menghubungi teater yang menggunakan karya pencipta tersebut. Teater bernegosiasi dengan lembaga mengenai penggunaan karya drama atau karya drama musikal (terutama mengenai royalti), kemudian dibuatlah kontrak khusus. Lembaga manajemen kolektif memungut royalti dan kemudian mendistribusikan kepada pencipta. Untuk teater amatir, mekanismenya lebih sederhana, pencipta melakukan pengalihan hak kepada lembaga manajemen kolektif untuk memotorisasi pertunjukan drama. 
d. Hak penggandaan reprografi karya sastra dan musik (the rights of reprographic reproduction of literrary and musical works)

Hak reprografi timbul karena kualitas mesin kopi yang semakin canggih sehingga dapat menghasilkan hasil salinan yang sangat mendekati aslinya. Contohnya ketika buku musik atau lembaran musik digandakan menggunakan alat fotokopi. Di beberapa negara hak reprografi dipertanyakan keabsahannya sehingga tidak semua negara mengimplementasikannya sebagai salah satu hak yang dapat dikelola. Berbeda halnya dengan hak mekanikal dimana orang merekam suara dan video untuk kepentingan hiburan, reprografi biasanya dilakukan untuk kepentingan pendidikan, perpustakaan, dan sejenisnya. Oleh karena itu penegakan terhadap hak reprografi biasanya terdapat pembatasan dan/atau pengecualian.

e. Resale right (droit de suite)

Di sebagian besar negara, ruang lingkup resale right hanya diterapkan pada hasil karya seni. Yang termasuk dari karya seni adalah lukisan, kolase, ukiran, cetakan (prints), lukisan pada logam (lithographs), patung, permadani (tapestries), keramik, barang pecah belah (glassware), fotografi. Pencipta seni awal yang telah menjual karya seninya, setelah jangka waktu tertentu, berhak mendapatkan royalti apabila karya seninya kemudian dijual kembali (biasanya melalui balai lelang seni) kepada pembeli berikutnya.

f. Rights of renumeration of Performers and Producers of Phonograms to the public of phonograms

Jika rekaman suara dilakukan untuk kepentingan komersiil, atau reproduksi dari rekaman suara terserbut digunakan secara langsung untuk penyiaran atau untuk segala komunikasi kepada publik, suatu remunerasi yang layak harus dibayarkan oleh pengguna kepada pelaku pertunjukan (artis) atau produser rekaman suara, atau kepada keduanya. Hak ini serupa dengan performing right sehingga pengelolaannya bisa dilakukan secara manajemen kolektif.

g. Rights in respect cable retransmission of broadcast programs

Dalam hal ini harus dibedakan antara program yang memang dibuat oleh TV kabel sendiri dan program bukan dibuat oleh TV kabel yang bersangkutan yang 
hanya merupakan tranmisi ulang tanpa perubahan. Untuk hal kedua inilah, hak pencipta atau royalti dalam program yang ditransmisikan ulang tersebut timbul dan dapat ditagih kepada pengguna.

\section{h. Private copying of phonograms and audiovisual works}

Hak ini lahir dari tindakan reproduksi karya cipta berupa perekaman yang digunakan untuk kepentingan pribadi, seperti perekaman dalam bentuk suara dan video dengan menggunakan alat perekam. Kewajiban untuk membayar royalti dikarenakan kepada manufaktur dan importir dari peralatan dan material perekam.

Berdasarkan uraian di atas, pada dasarnya lembaga manajemen kolektif membuat pencipta dan pemegang hak cipta serta pengguna dapat mengakses biaya transaksi yang lebih rendah. Dengan membuat biaya transaksi rendah, manajemen kolektif dapat meningkatkan jumlah hak-hak cipta yang dapat diperdagangkan. Menfasilitasi pertukaran atau perdagangan hak-hak cipta ini merupakan fungsi kunci dari manajemen kolektif dimana biaya transaksi akan menjadi berat jika pertukaran atau perdagangan tersebut dilakukan secara satu persatu, terutama jika dilakukan oleh individu dan pelaku bisnis kecil, yang berakibat tidak timbulnya perdagangan. Dengan semakin banyaknya pencipta dan pemegang hak cipta bergabung dalam manajemen kolektif, semakin menurunkan tingkat biaya transaksi sehingga menciptakan suatu skala ekonomis. Namun demikian disatu sisi yang lain, lembaga manajeman kolektif dapat menyalahgunakan posisi dominan atau sifat monopoli yang berakibat pada pengelolaan lembaga yang tidak efisien. Ketidakefisiensian ini dapat menggerus manfaat keberadaan lembaga manajemen kolektif.

Lembaga manajemen kolektif harus menjadi lembaga yang memberikan manfaat bagi pihak-pihak berkepentingan, yaitu pencipta, pemegang hak cipta, penerbit musik (music publisher) dan pengguna (user). Efisiensi merupakan ukuran penting dalam mengelola suatu lembaga manajemen kolektif. Lembaga manajemen kolektif harus mampu mengelola kepentingan-kepentingan pihak terkait secara 
efisien. ${ }^{11}$ Bagi pencipta/komposer efisiensi berarti kemampuan manajemen kolektif untuk mengumpulkan dan mendistribusikan royalti setinggi mungkin secara berkala (seperti sebulan sekali) untuk memastikan pembayaran segera dan adil. Bagi penerbit musik efisiensi berarti proses pembayaran yang cepat dengan biaya manajemen yang minimum berdasarkan tingkat royalti maksimum yang tidak tergerus oleh kompetisi diantara sesama lembaga manajemen kolektif.

\section{MODEL REGULASI TATA KELOLA LEMBAGA MENAJEMEN KOLEKTIF}

Model tata kelola lembaga manajemen kolektif yang dipraktikan di beberapa negara dapat digolongkan menjadi empat, yaitu model Recognition and Trust under Ex Post Control (Perancis), Benevolent Regulation with Ex Ante Control (Jerman), Co-Regulation (Inggris) dan Self-Regulation (Swedia). ${ }^{12}$ Pada dasarnya semua lembaga manajemen kolektif di negara yang tersebut untuk tingkat tertentu memiliki sifat monopolistis dalam pengelolaan hak cipta pencipta atau pemegang hak cipta, namun masing-masing negara mengatur secara rinci tentang jenis-jenis hak yang dapat dikelola yang satu negara dengan lainnya dapat berbeda. Berikut penjelasan singkat dari masing-masing model lembaga manajemen tersebut.

\section{A. Recognition and Trust under Ex Post Control Model (Perancis)}

Lembaga manajemen kolektif di Perancis dikenal sebagai sociétés de perceptions et de répartitions des droits. Lembaga ini biasanya diklasifikasikan dalam dua jenis, yaitu pertama, lembaga manajemen kolektif primer dengan tujuan utamanya membela kepentingan anggotanya (membership-based societies). Kedua, adalah lembaga intermediasi (societies of societies), yang terdiri dari beberapa lembaga manajemen kolektif sebagai platform bersama dalam menghimpun royalti. Legalitas lembaga manajemen kolektif di Perancis adalah persekutuan perdata atau civil law company, dan oleh karenanya merupakan lembaga nirlaba. Lembaga

${ }^{11}$ KEA-Eupean Affairs, The Collective Management of Rights in Europe. The Quest for Efficiency, Juli, 2006, h. 18-19.

12 Antonina Bakardjieva Engelbrekt, Toward Network Governance of Collective Management Organisations in Europe: The Problem of Institutional Diversity, in Karnell et al. (Ed.), Liber Amicorum Jan Rosén, Eddy, Oktober, 2016, h. 76-84. 
manajemen kolektif di Perancis tidak memiliki lembaga pengawas khusus. Ia hanya tunduk secara umum pada peradilan perdata (Pasal 1321-1 French Code of Intellectual Property/" CPI").

Karena merupakan lembaga nirlaba, lembaga manajemen kolektif tidak dipandang sebagai entitas ekonomi yang eksklusif melainkan dianggap sebagai lembaga kultural yang penting, yang memiliki misi kepentingan umum sejalan dengan filosofi hukum hak cipta Perancis. ${ }^{13}$ Oleh karenanya, dalam French Code of Intellectual Property, sebagian dari hasil pungutan royalti (25\%-50\%) yang tidak dapat dibagi (non-distributable) ${ }^{14}$ wajib digunakan untuk kegiatan pengembangan kreativitas, pertunjukan, dan kegiatan pelatihan untuk pelaku pertunjukan (Pasal 321-9 CPI).

Awalnya lembaga manajemen kolektif di Perancis tidak memerlukan ijin dari pemerintah sepanjang aktivitas mereka sesuai dengan peraturan perundangundangan. Ijin kepada Menteri Kebudayaan kemudian hanya diperlukan dalam pengelolaan hak tertentu yang wajib dikelola dalam lembaga manajemen kolektif (mandatory collective managment). ${ }^{15}$ Dalam praktiknya, semua lembaga manajemen kolektif diharuskan untuk menyerahkan anggaran dasar kepada Menteri Kebudayaan. Menteri Kebudayaan dapat meminta pengadilan membubarkan lembaga manajemen kolektif dengan alasan bertentangan dengan konstitusi. Perkembangan selanjutnya, akibat banyak terjadi kesalahan manajemen dalam pengelolaan lembaga, terdapat desakan oleh masyarakat untuk dilakukan pengawasan publik terhadap lembaga manajemen kolektif. ${ }^{16}$ Namun demikian, pengawasan masih bersifat ex-post dalam arti Menteri Kebudayaan dapat menginisiasi pemeriksaan terhadap lembaga manajemen kolektif dan kemudian tindak lanjut diserahkan kepada pengadilan untuk memutus.

Lembaga eksternal lain yang melakukan pengawasan terhadap lembaga manajemen kolektif adalah "La Commission Permanente De Contrôle Des Sociétés

\footnotetext{
${ }^{13}$ Ibid., h. 76.

14 Non distributable adalah pemasukan yang berasal dari karya yang sulit untuk diidentifikasi pihak yang berhak, seperti penarikan royalti pencipta asing.

15 ibid.

16 ibid., h. 77.
} 
De Perception Et De Répartition Des Droits” (Permanent Commission for Control of Royalty Collection and Distribution Societies). Lembaga ini tidak memiliki kewenangan untuk memberikan sanksi, melainkan hanya berupa kewenangan melakukan investigasi keuangan lembaga manajemen kolektif. Dengan demikian lembaga manajemen kolektif diawasi oleh dua lembaga yaitu Menteri Kebudayaan dan "La Commission Permanente De Contrôle Des Sociétés De Perception Et De Répartition Des Droits". Sifat pengawasan kedua lembaga tersebut adalah melakukan investigasi setelah diduga melakukan pelanggaran, oleh karenanya model pengawasan di Perancis dikenal sebagai "double-edged ex-post control" ${ }^{17}$

Besaran tarif dapat ditentukan secara negosiasi oleh para pihak, yaitu antara lembaga manajemen kolektif dengan pengguna. ${ }^{18}$ Pembagian atau pendistribusian pendapatan dilakukan sesuai skema yang ditentukan oleh lembaga manajemen kolektif. ${ }^{19}$ Terkait dengan aspek transparansi, setiap anggota (pencipta) lembaga manajemen kolektif berhak atas informasi berupa salinan laporan keuangan tahunan, daftar pengurus, laporan konsil administratif dan auditor, besaran umum remunerasi yang dibayarkan kepada penerima pembayaran terbesar (Pasal 321-5 CPI). ${ }^{20}$ Anggota yang mewakili sepuluh persen dari jumlah anggota, penuntut umum, dan dewan ketenagakerjaan dapat melakukan tindakan hukum untuk menunjuk ahli memeriksa dan membuat laporan kegiatan operasional tertentu dari lembaga manajemen kolektif (Pasal L.321-6 CPI).

Jenis-jenis hak pengelolaan yang wajib dikelola melalui lembaga manajemen kolektif berdasarkan peraturan perundang-undangan adalah sebagai berikut $^{21}$ :

- Reprography Right (Pasal L.122-12 CPI).

- Cable retransmission (Pasal L.132-20-1 CPI).

\footnotetext{
${ }^{17}$ Ibid. h. 78.

${ }^{18}$ KEA-European Affairs, op.cit., h.107.

19 ibid.

${ }^{20}$ ibid.

${ }^{21}$ KEA-European Affairs, op.cit., h.91.
} 
- Private copying (Pasal L. 311-6 CPI) ${ }^{22}$.

\section{B. Benevolent Regulation with Ex Ante Control Model (Jerman)}

Pengaturan seputar lembaga manajemen kolektif Jerman diatur dalam: (a) Undang-Undang Hak Cipta tahun 1965 sebagaimana diubah terakhir dengan Undang-Undang Hak Cipta dalam Masyarakat Informasi tahun 2003 (“UrhG”); (b) Undang-Undang tentang Administrasi Hak Cipta dan Hak Terkait tahun 1965 sebagaimana diubah terakhir dengan Undang-Undang Hak Cipta dalam Masyarakat Informasi tahun 2003 (Urheberrechtswahrnehmungsgesetz/ UrhWG). Undangundang ini secara komprehensif mengatur tata kelola lembaga manajemen kolektif mulai dari tentang pendirian, hubungan lembaga secara internal maupun dengan anggotanya, dan secara eksternal dengan pengguna (user) dengan prinsip transparansi.

Di Jerman, lembaga manajemen kolektif bukan merupakan institusi privat melainkan keberadaannya dianggap mempunyai tujuan untuk kepentingan publik. ${ }^{23}$ Bahkan berdasarkan Pasal 8 Undang-Undang Hak Cipta Jerman, lembaga manajemen kolektif diharuskan menyisihkan sebagian (10\%-30\%) dari pendapatan hasil penghimpunan royalti untuk menyediakan program kesejahteraan bagi anggotanya, seperti pembentukan lembaga pensiun.

Lembaga manajemen kolektif di Jerman diberikan otonomi yang besar. Pengawasan dan ijin pendirian dilakukan oleh German Patent and Trademark Office (DPMA). Dalam hal pemberian dan pencabutan ijin, DPMA berkoordinasi dengan lembaga anti-monopoli Jerman (Bundeskartellamt). Apabila terjadi perbedaan pendapat antara kedua lembaga tersebut mengenai pemberian dan pencabutan ijin lembaga manajemen kolektif, permasalahan ini kemudian diserahkan kepada Kementerian Kehakiman untuk memutus dengan berkoordinasi dengan Kementerian Ekonomi dan Energi. Pendekatan tata kelola lembaga

22 Dalam hal remunerasi untuk penyalinan pribadi, undang-undang tidak secara tegas menyebutkan pengelolaan oleh manajemen kolektif adalah wajib, meskipun dinyatakan bahwa pengumpulan harus dilaksanakan oleh oleh satu atau lebih lembaga manajemen kolektif.

${ }^{23}$ Antonina Bakardjieva Engelbrekt, loc.cit. 
manajemen kolektif di Jerman ini dikenal sebagai benevolent regulation. ${ }^{24}$ Selain pendekatan komprehensif dalam hal pengawasan oleh pemerintah, pendekatan yang digunakan oleh pemerintah dalam melakukan pengawasan lebih memberikan kebijakan yang mendukung lembaga manajemen kolektif.

Penentuan tarif atau remunerasi, lembaga manajemen kolektif melakukan negosiasi dengan pengguna demi kepentingan pemilik hak cipta dengan pengguna (Pasal 55(1) jo. Pasal 32(1) dan Pasal 49(1) Undang-Undang Hak Cipta Jerman). ${ }^{25}$ Pendistribusian dari pendapatan penghimpunan royalti ditentukan oleh lembaga manajemen kolektif tersebut. Dalam hal melaksanakan aspek transparansi, konsultasi harus dilakukan antara lembaga manajemen kolektif dan anggotanya dimana anggotanya memiliki hak atas informasi (Art. 57 (2) - (4) Undang-Undang Hak Cipta Jerman). ${ }^{26}$ Di samping itu, lembaga manajemen kolektif harus menyerahkan laporan keuangan kepada Kementerian Kebudayaan berdasarkan permohonan (Art. 54(5) Undang-Undang Hak Cipta Jerman).

Jenis-jenis hak yang wajib dikelola melalui lembaga manajemen kolektif berdasarkan peraturan perundang-undangan adalah sebagai berikut ${ }^{27}$ :

- Remuneration for cable retransmission (Pasal 20b UrhG);

- Resale right for artistic works (Pasal 26(5) UrhG);

- Remuneration for rental and lending of works (Pasal 27(3) UrhG);

- Remuneration for the reproduction and distribution of works for the benefit of disabled persons (Pasal 45a(2) UrhG);

- Remuneration for the reproduction and distribution of broadcast commentaries and individual articles from newspapers (Pasal 49(1) UrhG);

- Remuneration for the making available to the public of works for the purpose of teaching and research (Pasal 52a (4) UrhG);

- Remuneration for private copying (Pasal 54h UrhG).

\footnotetext{
${ }^{24}$ ibid., h. 79.

${ }^{25}$ KEA-European Affairs, op.cit.h. 107.

${ }^{26}$ ibid., h. 108

27 ibid., h. 92.
} 


\section{Antitrust Approach and Co-regulation Model (Inggris)}

Pendekatan model tata kelola lembaga manajemen kolektif di Inggris sangat berbeda dibandingkan dengan di negara Eropa kontinental. Lembaga manajemen kolektif secara tradisi dianggap sebagai lembaga privat dengan tujuan ekonomis dengan sangat sedikit dimensi kepentingan publiknya. ${ }^{28}$ Karena merupakan lembaga privat yang bertujuan keuntungan, tidak terdapat peraturan yang mensyaratkan lembaga manajemen kolektif untuk menyisihkan sebagian pendapatannya untuk kegiatan sosial dan budaya. Walaupun dalam praktiknya beberapa lembaga manajemen kolektif secara sukarela menyisihkan sebagian pendapatannya untuk menjalankan fungsi tersebut.

Berbeda dengan di Jerman, lembaga manajemen kolektif di Inggris dibentuk secara bebas dan tidak ada prosedural persetujuan oleh pemerintah. ${ }^{29}$ Sampai saat ini, rezim peraturan pada dasarnya mengandalkan hampir sepenuhnya pada pengaturan mandiri (self regulatory) walaupun terdapat peraturan perundangundangan yang menyingung mengenai keberadaan lembaga manajemen kolektif, seperti Copyright, Designs and Patents Act (“CDPA”) 1988. Peraturan perundangundangan ini hanya mengatur mengenai skema lisensi dan tarif serta pencegahan penyalahgunaan posisi monopoli. Skema lisensi dilakukan dengan basis sukarela, namun jika lisensi sukarela tidak dapat dijalankan, pengguna dapat meminta lisensi ke Peradilan Hak Cipta (Copyright Tribunal).

Model pengelolaan lembaga manajemen kolektif di Inggris ini disebut dengan pendekatan anti-monopoli (antitrust approach). ${ }^{30}$ Pendekatan anti monopoli sangat lazim digunakan di negara-negara common law yang sangat mengedepankan persaingan bebas. Campur tangan dalam hal pengawasan oleh pemerintah tidak dilakukan secara koersif melalui undang-undang, melainkan diatur melalui pembuatan Code of Practice yang dibuat oleh lembaga manajemen kolektif. Regulation of Relevant Licensing Bodies 2014 mempersyaratkan lembaga

\footnotetext{
${ }^{28}$ Antonina Bakardjieva Engelbrekt, loc.cit.

${ }^{29}$ ibid.

${ }^{30}$ ibid.
} 
manajemen kolektif mematuhi Code of Practice yang mengatur standar minimum tata kelola dan transparansi. Jika suatu badan lisensi tidak memiliki kode atau jika kode tersebut tidak memenuhi standar, the Secretary of State dapat menghimbau badan terkait untuk mengadopsi dan membuat kode tersebut. ${ }^{31}$ Kegagalan untuk mematuhi kode dapat dikenakan sanksi penalti. Regulation of Relevant Licensing Bodies 2014 juga mengatur kemungkinan penunjukan Code Reviewers dan Ombudsman bidang lisensi untuk menyelidiki dan memutus sengketa berdasarkan Code of Practice.

Pengaturan lembaga manajemen di Inggris ini mengikuti model peraturan bersama (co-regulation). Menurut model ini lembaga manajemen kolektif mengatur diri sendiri (self regulation) pada tahap pertama, tetapi pemerintah memiliki kewenangan yang diperlukan untuk menyelesaikan permasalahan yang timbul dalam pelaksanaan self-regulation serta menjatuhkan sanksi jika perlu.

Lembaga manajemen kolektif di Inggris dapat menentukan sendiri skema lisensinya. Kontrol anggota terhadap lembaga didasarkan pada ketentuan-ketentuan yang terdapat dalam anggaran dasar lembaga. ${ }^{32}$ Jika anggota lembaga ingin mengambil langkah hukum, hal tersebut hanya dapat dilakukan melalui peradilan umum.

Jenis-jenis hak yang wajib dikelola melalui lembaga manajemen kolektif berdasarkan peraturan perundang-undangan adalah sebagai berikut ${ }^{33}$ :

- Right to equitable remuneration of authors for the rental of sound recordings and films (Pasal 93B CDPA)

- Performers' right to equitable remuneration for the use of sounds recordings for playing in public and communication to the public except for electronic transmission

(Pasal 182D CDPA)

\footnotetext{
${ }^{31}$ ibid., h. 80.

${ }^{32}$ KEA-European Affairs, op.cit.h. 117.

33 ibid., h. 96.
} 
- Right to equitable remuneration of performers for the rental of sound recordings and films (Pasal 191G CDPA)

D. A Self-regulatory Approach Model (Swedia)

Pendekatan Swedia terhadap tata kelola lembaga manajemen kolektif memiliki tradisi khusus yang sudah berjalan mapan. Swedia mengambil tradisi kontinental berupa regulasi benevolent dan penghormatan terhadap peran sosial lembaga manajemen kolektif yang seluas mungkin. ${ }^{34}$ Ketiadaan campur tangan pemerintah dalam pengelolaan lembaga manajemen kolektif di Swedia ditegaskan dalam praturan perundang-undangan. Dalam Undang-Undang Hak Cipta Swedia (Act on Copyright in Literary and Artistic Works 1960 sebagaimana diubah pada 1 Juli 2005) disinggung mengenai lisensi kolektif namun dalam undang-undang tersebut sama sekali tidak terdapat aturan khusus mengenai perijinan dan pengawasan oleh pemerintah terhadap aktivitas lembaga. Pengawasan terhadap lembaga manajemen kolektif dilakukan berdasarkan aturan hukum perdata, seperti hukum perusahaan. Pengawasan terhadap kepatuhan peraturan ini dilakukan melalui pengadilan di mana pelanggaran dapat diancam sanksi hukum perdata, berupa kompensasi kerugian.

Kewajiban untuk menjalankan fungsi sosial dan budaya tidak disyaratkan dalam peraturan perundang-undangan. Namun dalam praktik, adalah hal biasa bagi lembaga manajemen kolektif menyumbangkan sebagian pendapatannya untuk kegiatan sosial, seperti menyumbang kepada suatu lembaga yang memiliki perhatian khusus terhadap pengembangan musik.

Sejumlah pengamat mengatakan bahwa pengelolaan lembaga manajemen kolektif di Swedia dengan pendekatan self-regulatory dibangun dalam banyak hal berdasarkan model hubungan industrial Swedia, dengan gerakan buruh yang kuat dan berpengaruh dan mengandalkan prosedur 'korporasi lunak' (soft corporatist) dalam menegosiasikan perjanjian bersama dan dalam penyelesaian konflik. ${ }^{35}$

\footnotetext{
${ }^{34}$ Antonina Bakardjieva Engelbrekt, op.cit., h. 81

35 ibid., h. 82.
} 
Dengan demikian, lembaga manajemen kolektif menjalankan fungsi intermediasi antara pencipta dan pengguna, yang menempatkan lembaga dalam posisi untuk mewakili kepentingan kolektif para pencipta dalam menerima remunerasi yang wajar untuk tenaga kerja mereka, seperti halnya serikat pekerja mewakili pekerja dalam bernegosiasi dengan industri.

Berdasarkan ketentuan peraturan perundang-undangan, tarif ditentukan dalam Undang-Undang Hak Cipta Swedia, yaitu sebesar 5\% dari nilai penjualan. ${ }^{36}$ Sementara pendistribusian pendapatan dilakukan berdasarkan rencana yang telah ditentukan oleh lembaga manajemen kolektif tersebut.

Jenis-jenis hak yang wajib dikelola melalui lembaga manajemen kolektif berdasarkan peraturan perundang-undangan adalah sebagai berikut ${ }^{37}$ :

- Remuneration for private copying (Pasal 26 huruf (m) dan Pasal 26 huruf (k), (1) UU Hak Cipta Swedia);

- The resale right for works of art (Pasal 26 huruf (j) UU Hak Cipta Swedia)

- The rights of reprographic reproduction (Pasal 42a-f UU Hak Cipta Swedia) Dalam hal reproduksi oleh otoritas dan perusahaan publik, lembaga pendidikan, perpustakaan dan arsip, untuk siaran suara, siaran radio atau televisi, dan untuk transmisi ulang karya yang terkandung dalam siaran suara dan radio

- Remuneration for the simultaneous and unabridged cable retransmission of phonograms (Pasal 47 UU Hak Cipta Swedia)

- Remunerasi untuk penyiaran dan pertunjukan publik dari fonogram harus dikelola bersama oleh pemain dan produser (Pasal 47 UU Hak Cipta Swedia)

${ }^{36}$ KEA-European Affairs, op.cit., h. 117.

37 ibid., h. 97. 
Tabel 1. Perbandingan Tata Kelola Lembaga Manajemen Kolektif

\begin{tabular}{|c|c|c|c|c|}
\hline & PERANCIS & JERMAN & INGGRIS & SWEDIA \\
\hline $\begin{array}{l}\text { Tujuan Badan } \\
\text { Hukum }\end{array}$ & $\begin{array}{l}\text { Nirlaba/kepenting } \\
\text { an publik }\end{array}$ & $\begin{array}{l}\text { Nirlaba/kepentingan } \\
\text { publik }\end{array}$ & $\begin{array}{l}\text { Keuntungan } \\
\text { //swasata }\end{array}$ & $\begin{array}{l}\text { nirlaba/kepenti } \\
\text { ngan publik }\end{array}$ \\
\hline Penentuan Tarif & Negosiasi & Negosiasi & $\begin{array}{l}\text { Ditentukan } \\
\text { lembaga }\end{array}$ & $\begin{array}{l}\text { Untuk } \\
\text { beberapa } \\
\text { ditentukan } \\
\text { oleh undang- } \\
\text { undang }\end{array}$ \\
\hline $\begin{array}{l}\text { Pendistribusian } \\
\text { Hasil }\end{array}$ & $\begin{array}{l}\text { Ditentukan } \\
\text { Lembaga }\end{array}$ & Ditentukan Lembaga & $\begin{array}{l}\text { Ditentukan } \\
\text { lembaga }\end{array}$ & $\begin{array}{l}\text { Ditentukan } \\
\text { oleh Lembaga }\end{array}$ \\
\hline Transparansi & $\begin{array}{l}\text { Anggota berhak } \\
\text { mendapatkan } \\
\text { laporan keuangan }\end{array}$ & $\begin{array}{l}\text { Anggota berhak } \\
\text { mendapatkan } \\
\text { laporan keuangan } \\
\text { dan harus ada } \\
\text { konsultasi antara } \\
\text { lembaga dan anggota }\end{array}$ & $\begin{array}{l}\text { Tidak diatur } \\
\text { undang- } \\
\text { undang }\end{array}$ & $\begin{array}{l}\text { Tidak diatur } \\
\text { undang- } \\
\text { undang }\end{array}$ \\
\hline \begin{tabular}{l}
\multicolumn{2}{l}{ Kewajiban } \\
Fungsi $\quad$ Sosial \\
Budaya
\end{tabular} & $\begin{array}{l}\text { Diwajibkan } \\
\text { menyisihkan } \\
\text { pendapatan untuk } \\
\text { kegiatan sosial } \\
\text { budaya }\end{array}$ & $\begin{array}{l}\text { Diwajibkan } \\
\text { menyisihkan } \\
\text { pendapatan untuk } \\
\text { kesejahteraan } \\
\text { anggota (pensiun) }\end{array}$ & $\begin{array}{l}\text { Tidak diatur } \\
\text { undang- } \\
\text { undang }\end{array}$ & $\begin{array}{l}\text { Tidak } \\
\text { diwajibkan }\end{array}$ \\
\hline $\begin{array}{l}\text { Pengawasan } \\
\text { Eksternal }\end{array}$ & $\begin{array}{l}\text { Menteri } \\
\text { Kebudayaan dan } \\
\text { La commission } \\
\text { permanente de } \\
\text { contrôle des } \\
\text { sociétés de } \\
\text { perception et de } \\
\text { répartition des }\end{array}$ & $\begin{array}{l}\text { German Patent and } \\
\text { Trademark Office }\end{array}$ & $\begin{array}{l}\text { Co- } \\
\text { regulation } \\
\text { (self- } \\
\text { regulatory } \\
\text { dilengkapi } \\
\text { dengan } \\
\text { pengawasan } \\
\text { oleh }\end{array}$ & Self regultory \\
\hline
\end{tabular}




\begin{tabular}{|l|l|l|l|l|}
\hline & droits namun & & pemerintah & \\
sebatas & & yang & terbatas $)$ & \\
kewenangan & & & \\
investigasi tidak & & & \\
memberikan & & & \\
sanksi & & & \\
\hline
\end{tabular}

\section{ANALISIS REGULASI TATA KELOLA LEMBAGA MANAJEMEN KOLEKTIF INDONESIA}

\section{Aspek Pengawasan}

Dalam hal pengawasan, Pasal 92 UU Hak Cipta, menentukan lembaga manajemen kolektif diawasi oleh Menteri Hukum dan HAM yang melaksanakan evaluasi kinerja minimal 1 kali dan setahun. Dalam hal ini, oleh undang-undang Menteri diberikan kewenangan untuk mencabut izin operasional lembaga manajemen kolektif apabila tidak memenuhi ketentuan dalam undang-undang tersebut.

Sebelum diberlakukannya UU Hak Cipta tidak ada pengawas eksternal khusus untuk mensupervisi lembaga manajemen kolektif. Keberadaan lembaga manajemen kolektif pada waktu itu hanya lahir dari hubungan keperdataan. Sekelompok pencipta membentuk suatu badan hukum, kemudian melakukan perjanjian pemberian kuasa dengan para pencipta dan melakukan perjanjian lisensi dengan pengguna. Kesemuanya ini dilakukan dalam kerangka hukum perdata.

Pada waktu itu Lembaga Manajemen Kolektif yang ada di antaranya adalah Yayasan Karya Cipta Indonesia (YKCI), Asosiasi Industri Rekaman Indonesia (ASIRI), Wahana Musik Indonesia (WAMI). Pengakuan pemerintah terhadap lembaga semacan YKCI sebagai tercipta secara tidak langsung, yaitu hanya tergambar dari Perjanjian Kerjasama Antara Direktorat Hak Cipta, Hak Cipta dan Merek Direktorat Jenderal Hak dan Kekayaan Intelektual (Ditjen HKI) dengan YKCI pada 23 September 1998. Kala itu, YKCI diwakili oleh Rinto Harahap, sedangkan Ditjen HKI diwakili S. Kayatmo. YKCI merupakan badan administrasi 
kolektif untuk mengurus performing right suatu karya cipta lagu yang didirikan berdasarkan Akta Notaris Nomor 42 tertanggal 12 Juni 1990. Pakar hukum Hak Kekayaan Intelektual (HKI) Insan Budi Maulana berpendapat pada dasarnya lembaga manajemen seperti YKCI hanya berperan untuk mempermudah pencipta mendapat hak-hak atas karya mereka ${ }^{38}$. Lembaga Manajemen Kolektif hanya berperan sebagai fasilitator yang memudahkan pencipta, daripada secara perseorangan pencipta menagih sendiri hak mereka. Dasar pemberian kuasa oleh pemegang hak cipta kepada Lembaga Manajemen Kolektif ini adalah dengan mendasarkan pada konsep pemberian kuasa yang diatur dalam Pasal 1792 KUHPerdata.

Dengan demikian, sebelum diberlakukannya UU Hak Cipta 2014 tidak ada pengaturan secara spesifik mengenai Lembaga Manajemen Kolektif yang secara tegas pengakuan terhadap keberadaan Lembaga Manajemen Kolektif. Sebab, sebelumnya keberadaan lembaga semacam YKCI hanya berdasar pada hubungan keperdataan tanpa pengakuan tegas dari Undang-undang.

Dengan demikian, sebelum UU Hak Cipta 2014, model pengelolaan lembaga manajemen kolektif di Indonesia mengikuti model pengelolaan mandiri (self-regulatory) sebagaimana dilakukan oleh negara Swedia dan Inggris. Di kedua negara tersebut model self regulatory dapat berjalan, namun tidak di Indonesia. Model self regulatory dapat bekerja dengan baik di Swedia dan Inggris satu dan lain hal disebabkan oleh tradisi dan budaya hukum negara tersebut dalam mengatur institusi sosialnya ${ }^{39}$.

\footnotetext{
${ }^{38}$ Menatap Masa Depan Collecting Society," $<$ http://www.hukumonline.com/berita/baca/hol18762/menatap-masa-depan-icollecting-societyi>,

39 Skandinavia, dimana Swedia termasuk salah satu di dalamnya, mempunyai tradisi penghormatan atas pengaturan institusi sosialnya dengan mengedepankan prinsip self-regulatory yang yang juga didasarkan pada prinsip communitarian. Prinsip communitarian menghindarkan pengaturan institusi sosialnya diserahkan baik kepada pasar (dalam hal liberal kapitalis) maupun secara absolut diatur oleh negara. Sementara di Inggris penganut paham leize faire atau liberalindividualis sangat mengedepankan kebebasan individu dimana campur tangan negera sebisa mungkin dikesampingkan. Campur tangan negara hanya diperlukan jika dan hanya jika untuk menjamin kebebasan individu itu sendiri. Oleh karenanya negara Inggris untuk tingkat tertentu dapat dikategorikan negara yang mengedepankan prinsip sel regulatory dalam mengatur institusi sosialnya. Ketaatan hukum masyarakat Inggris yang menghindari campur tangan atau tindakan pengawasan dari kekuasaan didukung oleh tradisi orang Inggris yang disebut dengan prinsip gentlemen's agreement, yaitu kesepakatan yang biasanya dilakukan secara informal, kadang tidak
} 
Akibat ketiadaan lembaga pengawas eksternal sering timbul sengketa antara lembaga manajemn kolektif dengan pencipta dan pengguna. Abdul Bari Azed, Sekretaris Jenderal Kementerian Hukum dan Hak Asasi Manusia (Sekjen Kemenkumham), mengungkapkan sengketa kewenangan pemungutan royalti hak cipta kerap kali timbul karena tidak adanya perangkat perundangundangan yang secara tegas dan rinci mengatur mengenai hal tersebut ${ }^{40}$. Oleh karena itu, menurutnya, salah satu poin pembahasan yang cukup penting dalam merevisi Undang-undang Nomor 19 Tahun 2002 tentang Hak Cipta (UU Hak Cipta) adalah mengenai lembaga manajemen kolektif yang diberikan kuasa oleh pemegang hak cipta untuk menarik royalti hak cipta lagu.

\section{Sifat Mandatory dan Jenis-Jenis Hak yang Dikelola}

Legalitas lembaga manajemen kolektif di Indonesia berdasarkan undangundang adalah badan hukum nirlaba (Pasal 88 ayat (2) huruf (a) Undang-Undang Hak Cipta 2014). Lembaga manajemen kolektif secara esensiil memiliki kewenangan dalam mengurus royalti pencipta dari penggunaan oleh pengguna seperti restoran, diskotik, karaoke dan lain-lain. Kewenangan ini dapat dilihat dari ketentuan Pasal 87 ayat (1) dan (2) Undang-Undang Hak Cipta 2014 yang berbunyi sebagai berikut:

(1) Untuk mendapatkan hak ekonomi setiap Pencipta, Pemegang Hak Cipta, pemilik Hak Terkait menjadi anggota Lembaga Manajemen Kolektif agar dapat menarik imbalan yang wajar dari pengguna yang memanfaatkan Hak Cipta dan Hak Terkait dalam bentuk layanan publik yang bersifat komersial.

(2) Pengguna Hak Cipta dan Hak Terkait yang memanfaatkan Hak sebagaimana dimaksud pada ayat (1) membayar Royalti kepada

tertulis, namun tetap disepakati. Penegakannya tidak digantungkan pada rasa takut akan sanksi hukum melainkan lebih mendasarkan pada kehormatan (honor) dari para pihak untuk memenuhi kewajiban hukumnya. Lihat Ka Lin, Cultural Traditions and the Scandinavian Social Policy Model, Social Policy \& Administration, November, 2005.

${ }^{40}$ Pemerintah Bahas Royalti Lagu,
http://www.hukumonline.com/berita/baca/hol16351/pemerintah-bahas-pungutan-royalti-lagu. 
Pencipta, Pemegang Hak Cipta, atau pemilik Hak Terkait, melalui Lembaga Manajemen Kolektif."

Dari ketentuan Pasal 87 ayat (1) memang tidak secara tegas mengenai kewajiban bagi para pencipta/pemegang hak cipta hanya boleh menarik royaltinya melalui dan bagi pengguna hanya boleh membayar royalti lembaga manajemen kolektif karena tidak terdapat kata "wajib/harus", yang berarti memberikan monopoli kepada lembaga manajemen kolektif atau kata “dapat” yang berarti tidak memberikan status monopoli. Apabila kita memandang klausula tersebut tidak bersifat memaksa atau mandatory, maka penarikan royalti dapat dilakukan hanya dengan kontraktual antara individu pencipta dengan penggunanya, tidak harus melalui lembaga manajemen kolektif, sehingga dengan interpretasi seperti ini tidak memberikan status monopoli kepada lembaga tersebut.

Namun jika dilakukan interpretasi secara sistematis, dalam Pasal 89 ayat (2) Undang-Undang Hak Cipta 2014 berbunyi:

“Kedua Lembaga Manajemen Kolektif sebagaimana dimaksud pada ayat (1) memiliki kewenangan untuk menarik, menghimpun, dan mendistribusikan Royalti dari Pengguna yang bersifat komersial”.

Adanya kata "kewenangan" yang terdapat dalam undang-undang ini menunjukan bahwa kewenangan suatu lembaga untuk menarik dan mendistribusikan royalti hanya timbul apabila dinyatakan dalam suatu undang-undang. Sebagaimana diketahui, kewenangan yang timbul dari suatu undang-undang adalah termasuk dalam ranah hukum publik.

Yang menjadi permasalahan disini adalah, apakah jika ada suatu kewenangan yang diberikan oleh undang-undang untuk melaksanakan sesuatu tindakan (dhi. penarikan dan pendistribusian royalti), pada saat bersamaan dimungkinkan timbulnya suatu kewenangan untuk melaksanakan suatu tindakan yang sama yang lahir dari hubungan kontraktual (yang merupakan ranah hukum privat). Dengan demikian seharusnya tidak boleh ada mekanisme penarikan, penghimpunan dan pendistribusian royalti yang berkaitan dengan hak cipta tanpa melalui lembaga manajemen kolektif. Jika pencipta atau pemegang hak cipta secara individu dapat menarik dan menghimpun royalti tanpa melalui lembaga manajemen 
kolektif, seharusnya kewenangan atau pengecualian ini juga harus dinyatakan secara tegas dalam undang-undang yang sama yang memberikan kewenangan lembaga manajemen kolektif untuk menarik dan mendistribusikan royalti.

Oleh karena itu, berdasarkan penafsiran sistematis diatas, bagi pencipta yang ingin menarik royalti dari pengguna mau tidak mau harus melalui Lembaga Manajemen Kolektif. Demikian pula sebaliknya bagi pengguna (restoran, diskotik, karaoke) untuk melakukan pembayaran royalti, berdasarkan ketentuan ayat (2) Pasal 89, hal ini harus dilakukan melalui Lembaga Manajemen Kolektif. Dengan demikian, undang-undang ini memberkan "semacam" monopoli kepada lembaga manajemen kolektif. Dikatakan "semacam” karena sifat keharusan (mandatory) ini, dimana pencipta tidak dapat manarik royalti atas ciptaannya kecuali melalui Lembaga Manajemen Kolektif dan pengguna tidak dapat membayar royalti tanpa melalui Lembaga Manajemen Kolektif, memberikan "semacam" hak monopoli kepada lembaga manajemen kolektif. Tentu "monopoli" disini tidak dimaksudkan bahwa hanya boleh ada satu-satunya lembaga manajemen kolektif. Pencipta yang tidak puas terhadap pelayanan yang diberikan oleh suatu lembaga manajemen kolektif dapat memilih lembaga manajemen kolektif lainnya.

Jika lembaga manajeman kolektif diberikan "semacam" hak monopoli oleh undang-undang, permasalahan yang timbul kemudian adalah UU Hak Cipta 2014 tidak memberikan batasan ruang lingkup jenis-jenis hak pengelolaan apa saja yang dapat dikelola oleh lembaga manajemen kolektif. Dalam praktik dan perbandingan dengan negara lain, terdapat jenis hak pengelolaan yang dapat dilakukan atau dengan kata lain lebih efisien dilakukan negosiasi secara individu antara pencipta dengan pengguna secara langsung tanpa melalui suatu lembaga manajemen kolektif, seperti karya drama musikal. Pada area audiovisual, pengelolaan hak dilakukan negosiasi langsung antara pengguna dan produser, tanpa melalui lembaga perantara $^{41}$. Pengelolaan hak yang timbul dari karya film sulit dilakukan melalui mekanisme lembaga kolektif karena pihak produser film yang biasanya melakukan penarikan hak-hak yang timbul dari karya film ${ }^{42}$. Perusahaan rekaman besar (major

\footnotetext{
${ }^{41}$ KEA-European Affairs, op.cit., h. 28.

42 ibid., h. 29.
} 
record companies) memberikan lisensi untuk musik video secara langsung sendiri kepada MTVE, saluran televisi musik video internasional terbesar. ${ }^{43}$

Oleh karena itu seharusnya undang-undang hak cipta Indonesia memberikan batasan ruang lingkup jenis-jenis hak pengelolaan yang dapat atau harus dikelola oleh lembaga manajemn kolektif. Sebagai masukan rujukan dapat diambil dari pengaturan yang dilakukan oleh negara-negara di Eropa sebagaimana telah diuraikan sebelumnya di atas. Salah satu rujukan yang dapat digunakan adalah negara Jerman dimana undang-undang mewajibkan jenis-jenis hak dibawah ini dikelola oleh lembaga manajemen kolektif, yaitu: remuneration for cable retransmission, resale right for artistic works, remuneration for rental and lending of works, remuneration for the reproduction and distribution of works for the benefit

of disabled persons, remuneration for the reproduction and distribution of broadcast commentaries and individual articles from newspapers, dan remuneration for the making available to the public of works for the purpose of teaching and research.

\section{Fungsi Sosial Dan Budaya Lembaga Manajemen Kolektif}

UU Hak Cipta 2014 secara tegas mendefinisikan Lembaga Manajemen Kolektif sebagai institusi yang berbentuk badan hukum nirlaba yang diberi kuasa oleh Pencipta, Pemegang Hak Cipta, dan/atau pemilik hak terkait guna mengelola hak ekonominya dalam bentuk menghimpun dan mendistribusikan royalti. Kemudian untuk mendapatkan imbalan, pencipta atau pemilik hak terkait harus menjadi anggota Lembaga Manajemen Kolektif dari pengguna (user) seperti restoran, karaoke, diskotek dan sebagaimana ${ }^{44}$. Pengertian nirlaba berdasarkan Kamus Besar Bahasa Indonesia diartikan sebagai bersifat tidak mengutamakan pemerolehan keuntungan. ${ }^{45}$ Tradisi negara Civil law, seperti Indonesia, dalam mengartikan konsep nirlaba biasanya mengkaitkan dengan pengklasifikasian antara

\footnotetext{
43 ibid., h. 31.

${ }^{44}$ Pasal 87 ayat (1) UUHC 2014

45 https://www.kbbi.web.id/nirlaba
} 
badan hukum publik dan badan hukum privat. Ia merupakan badan hukum perdata jika didirikan oleh perseorangan, sedangkan pada badan hukum publik jika diadakan oleh kekuasaan umum. Sementara pembagian badan hukum privat sendiri dapat dilihat tujuannya, yaitu badan hukum yang memiliki tujuan untuk keuntungan seperti korporasi atau perseroan terbatas, badan hukum yang bertujuan untuk kepentingan sosial, keagamaan dan pendidikan seperti yayasan, dan badan hukum yang bertujuan untuk kesejahteraan anggotanya seperti koperasi.

Dengan demikian lembaga manajemen kolektif sebagai badan hukum nirlaba berarti yang jelas ia tidak dapat berbentuk perseroan terbatas, melainkan yayasan, koperasi (ataupun perkumpulan berbadan hukum berdasarkan KUHPerdata). Konsekuensinya lembaga manajemen kolektif, oleh karenanya, dalam kaitannya dengan hak cipta di bidang musik/lagu harus lebih mengutamakan tujuan untuk kepentingan sosial, dalam hal memajukan kesenian ataupun bertujuan mengutamakan kesejahteraan anggotanya, yang dalam hal ini adalah para pencipta.

Perlindungan hak cipta antara lain adalah memberikan insentif untuk berkarya kepada para pencipta dengan memberikan manfaat ekonomis. Sebagaimana permasalahan terhadap konsep intelektual properti lainnya, perlindungan hak cipta selain memberikan insentif bagi pencipta tetapi juga disatu sisi dapat memberikan manfaat bagi masyarakat berupa tersedianya jumlah dan penyebaraan karya-karya yang diperlukan dan berguna bagi masyarakat. Bagaimanapun hak cipta memberikan hak monopoli kepada pemegangnya sehingga berpotensi menghambat dan mengurangi jumlah karya-karya yang sangat diperlukan oleh masyarakat. Dengan demikian, untuk menyeimbangkan antara biaya sosial (akibat monopoli dan keuntungan ekonomis yang diberikan kepada pencipta) dan manfaat sosial (tersedianya karya-karya yang diperlukan oleh masyarakat), adalah dengan membebankan kewajiban menyisihkan sebagian pendapatan kepada lembaga manajemen kolektif untuk melaksanakan program seni dan kebudayaan. Sebagian besar negara Eropa mewajiban dalam suatu undangundang untuk lembaga manajemen kolektif untuk menyisihkan sebagian 
pendapatannya untuk UU Hak Cipta 2014 hanya menentukan penggunaan pendapatan terkait dengan peruntukan biaya operasional, dimana lembaga hanya dapat menggunakan dana operasional paling banyak 20\% (dua puluh persen) dari jumlah keseluruhan Royalti yang dikumpulkan setiap tahunnya kecuali pada 5 (lima) tahun pertama, lembaga dapat menggunakan sampai dengan 30\% (tiga puluh persen) untuk dana operasional. Undang-undang ini sama sekali tidak menyinggung kewajiban menjalankan fungsi sosial dan budaya bagi lembaga manajemen kolektif.

Kemudian, terdapat suatu permasalahan yang sering dihadapi oleh para pencipta musik/lagu, yaitu jaminan hari tua. Permasalahan ini sesuai dengan yang dikemukakan oleh Tompi, “..para musisi sering terjebak kenyamanan semu...Banyak musisi yang menurut dia memiliki mendapat sukses dan kaya raya di masa muda, namun menghadapi kesulitan di masa tua". ${ }^{46}$ Sudah bukan menjadi isapan jempol bila kesejahteraan musisi di Indonesia terbilang cukup buruk. Para musisi mengeluarkan karya gemilang yang bisa dinikmati oleh seluruh masyarakat, namun di masa tuanya, mereka seolah-olah terlupakan. ${ }^{47}$ Banyak dari musisi ternama Indonesia yang di akhir hayatnya harus hidup susah, bahkan tak bisa membiayai pengobatannya sendiri. Padahal, karya mereka masih sering diputar hingga saat ini. Banyak pencipta lagu atau pemusik yang belum memahami keberadaan dan fungsi dari lembaga manajemen kolektif. Hal ini diungkap oleh Makki Parikesit, personil band UNGU bahwa "... mengakui kalangan pemusik memang masih bingung tentang keberadaan LMK. Dia bahkan berani menyebut sekitar 90 persen pemusik belum begitu paham pentingnya LMK...Mereka (pemusik) sepertinya tidak paham kalau hak mereka dibela oleh LMK-LMK ini”. ${ }^{48}$

46 Tiga masalah industri musik Indonesia saat ini, AntaraNews.com., Kamis, 9 Maret, 2017. https://www.antaranews.com/berita/617098/tiga-masalah-industri-musik-indonesia-saat-ini

475 Musisi yang Memperjuangkan Hak Royalti di Indonesia, Kumparan, 9 Maret, 2018. https://kumparan.com/@kumparanhits/5-musisi-yang-memperjuangkan-hak-royalti-di-indonesia

48 Pro Kontra Eksistensi Lembaga Manajemen Kolektif, Pemusik menilai peran LMK belum maksimal, Hukumonline, Selasa, $30 \quad$ April, 2013. https://www.hukumonline.com/berita/baca/lt517fd780019e8/pro-kontra-eksistensi-lembagamanajemen-kolektif 
Oleh karena itu sudah seyogyanya dalam regulasi di Indonesia untuk mewajibkan lembaga manajemen menyisihkan sebagian pendapatannya untuk melakukan kegiatan program pengembangan seni dan budaya serta menyusun program pensiun bagi para pencipta individual yang merupakan anggota sebagaimana dilakukan oleh negera Jerman. Untuk mewujudkan hal ini lembaga manajemen kolektif dapat bekerjasama dengan BPJS Ketenagakerjaan.

\section{Aspek Transparansi dan Akuntabilitas}

Lembaga Manajemen Kolektif sebagai lembaga yang mengelola hak ekonomi pencipta/pemegang hak cipta, kinerjanya harus transparan dan akuntabel. Transparansi merupakan salah satu karakteristik penting dalam good governance ${ }^{49}$. Transparansi ditujukan untuk membangun kepercayaan. Transparansi dan akuntabilitas merupakan dua konsep yang sangat terkait. Menurut Logos (2003) transparansi dan akuntabilitas merupakan konsep yang berkaitan erat satu dengan yang lain, karena tanpa transparansi tidak mungkin ada akuntabilitas. Sebaliknya transparansi tidak akan banyak bermanfaat tanpa dilengkapi dengan akuntabilitas. Seperti halnya di bidang kebijakan publik yang lain, keberadaan transparansi dan akuntabilitas merupakan syarat mutlak untuk membangun kebijakan dan institusi yang efektif, efisien, dan adil (equitable).

Transparansi dan akuntabilitas sangat penting untuk berfungsinya ekonomi modern secara efisien dan untuk menjaga kesejahteraan sosial. Di sebagian besar masyarakat, banyak kekuasaan didelegasikan kepada suatu lembaga. Jaminan harus

\footnotetext{
${ }^{49}$ United Nations for Development Program (UNDP) telah menyusun karakteristik penting dalam good governance, yaitu (Mardiasmo, 2002): (1) Participation, yaitu keterlibatan masyarakat dalam pembuatan keputusan baik secara langsung maupun tidak langsung melalui lembaga perwakilan; (2) Rule of law, yaitu kerangka hukum yang adil dan tanpa pandang bulu; (3) Transparancy, yaitu kebebasan mendapatkan informasi yang berkaitan dengan kepentingan publik (4) Responsiveness, yaitu kecepatan dan daya tanggap lembaga publik dalam memberikan layanan kepada stakeholder (5) Consensus Orientation, yaitu berorientasi pada kepentingan masyarakat luas; (6) Equity, yaitu setiap masyarakat memiliki kesempatan yang sama untuk memperoleh kesejahteraan dan keadilan; (7) Efficiency and Effektiveness, yaitu pengelolaan sumber daya publik dilakukan secara berdaya guna dan berhasil guna; (8) Accountability, yaitu pertanggungjawaban kepada publik atas setiap aktifitas yang dilakukan; (9) Strategic vision, yaitu penyelenggara pemerintahan dan masyarakat harus memiliki visi jauh kedepan. Lihat Mardiasmo,Akuntansi Sektor Publik, 2004, Penerbit Andi.
} 
diberikan kepada bahwa kewengan yang diberikan tidak hanya efektif, tetapi juga tidak disalahgunakan. Transparansi memastikan bahwa informasi tersedia yang dapat digunakan untuk mengukur kinerja pihak yang diberi kewenangan dan untuk mencegah kemungkinan penyalahgunaan kekuasaan. Dalam hal itu, transparansi berfungsi untuk mencapai akuntabilitas, yang berarti bahwa pihak berwenang bertanggung jawab atas tindakan mereka. Tanpa transparansi dan akuntabilitas, kepercayaan antara para pihak yang terkait. Hasilnya adalah ketidakstabilan sosial dan lingkungan yang kurang kondusif bagi pertumbuhan bisnis dan ekonomi.

Transparansi oleh lembaga manajemen kolektif dengan demikian dapat menimbulkan kepercayaan bagi anggotanya, dalam hal ini pencipta dan pemegang hak cipta, bahwa lembaga telah dikelola dengan tidak merugikan mereka. Para anggota dapat mengetahui kinerja lembaga dalam hal, berapa banyak pendapatan royalti yang telah dihimpun dan penggunaannya sehingga jika terjadi penyalahgunaan dapat dengan mudah dideteksi. Sehingga anggota dapat mengukur dan mengevaluasi kinerja lembaga sehingga menumbukan kepercayaan kepada lembaga.

Transparansi dalam lembaga manajemen kolektif juga didorong oleh upaya untuk membuat proses lisensi lebih mudah dipahami oleh pengguna. Idenya adalah bahwa jika pengguna (pemegang lisensi) dengan jelas memahami mengapa ia harus membayar dan bagaimana biaya sebenarnya dihitung, kesediaan mereka untuk membayar, dan karenanya pendapatan yang dikumpulkan akan meningkat. Transparansi di sini berarti mengetahui apa yang harus mereka bayar dan berapa banyak.

Pasal 90 UU Hak Cipta 2014 telah mewajibkan lembaga manajemen kolektif untuk melaksanakan audit keuangan dan kinerja oleh akuntan publik setahun sekali dan diumumkan kepada masyarakat setiap tahun. Namun undangundang tersebut maupun peraturan pelaksana terkait tidak mengatur standar substansi yang harus disajikan yang merupakan spesifik pengelolaan lembaga manajemen kolektif. Sebagai rujukan hal-hal apa yang harus dimuat dalam laporan 
tersebut dapat mengambil model negara-negara di Eropa yang mewajiban lembaga untuk memuat hal-hal yang dilaporkan berupa ${ }^{50}$ :

- Operasional lembaga.,

- Aturan organisasi.,

- Perijinan operasional.,

- Aturan pendistribusian.,

- Tarif.,

- Repertoire.,

- Daftar dan detil para pengurus.,

- Laporan publik dan resolusi.,

\section{KESIMPULAN DAN SARAN}

\section{A. Kesimpulan}

1. Lembaga manajemen kolektif membuat pasar berfungsi dengan memastikan keefektifan hak cipta dimana pemilik hak cipta tidak mungkin melakukan kontrak secara langsung. Lembaga manajemen kolektif membuat pencipta dan pemegang hak cipta serta pengguna dapat mengakses biaya transaksi yang lebih rendah sehingga dapat meningkatkan jumlah hak-hak cipta yang dapat diperdagangkan. Namun di sisi yang lain, lembaga manajeman kolektif dapat menyalahgunakan posisi dominan atau sifat monopoli yang berakibat pada pengelolaan lembaga yang tidak efisien. Oleh karena itu, pengelolaan lembaga manajemen kolektif harus didasarkan pada tata kelola (governance) yang baik. Implementasi tata kelola yang baik sebaiknya dimasukan dalam kerangka regulasi mengenai lembaga manajemen kolektif.

2. Sejak diberlakukannya UU Hak Cipta 2014, pengaturan lembaga manajemen kolektif di Indonesia menggunakan model pengawasan pemerintah, dalam hal ini Kementerian Hukum dan Hak Azasi Manusia, dimana sebelum diberlakukannya undang-undang tersebut, pengawasan lebih menyerupai model self-regulatory, dimana hubungan para pihak yang berkepentingan

${ }^{50}$ KEA-European Affairs, op.cit., h. 75 
menggunakan kerangka hukum perdata. Walaupun Undang-Undang Hak Cipta 2014 telah memberikan landasan hukum keberadaan lembaga manajemen kolektif, pengaturan yang lebih detil perlu dilakukan.

3. Model pengawasan lembaga manajemen kolektif di negara Eropa bervariasi dari pengawasan secara komprehensif oleh pemerintah, seperti di Jerman, sampai dengan model pengawasan mandiri atau self-regulatory, seperti di Swedia dan Inggris. Negara-negara dengan keterlibatan supervisi pemerintah, seperti Perancis dan Jerman, peraturan perundang-undangan mensyaratkan penyisihan sebagian pendapatan lembaga manajemen kolektif untuk digunakan pengembangan program seni budaya serta kesejahteraan anggota, seperti di Jerman. Negara-negara dengan tradisi self-regulatory, seperti Swedia dan Inggris, tidak mempersyaratkan lembaga manajemen kolektif menjalankan fungsi seperti itu. Walaupun tidak dipersyaratkan oleh peraturan perundangundangan, lembaga manajemen kolektif di negara-negara ini dalam praktiknya menyisihkan sebagian pendapatannya untuk kegiatan pengembangan seni dan budaya. Transparansi dan akuntabilitas merupakan aspek penting dalam tata kelola di negara-negara ini dari hak anggota atas informasi keuangan dan kewajiban lembaga untuk menyerahkan dan/atau mempublikasikan laporannya ke publik dan/atau lembaga pengawas.

\section{B. Saran}

1. Lembaga manajemen kolektif di Indonesia sebaiknya tetap menggunakan model pengawasan dari pemerintah dan pengaturan yang memberikan "semacam" hak monopolistik bagi lembaga manajemen kolektif dalam mengelola hak-hak ekonomi pencipta atau pemegang hak cipta. Namun demikian, sebagaimana praktik terbaik di negara-negara Eropa, undangundang negara-negara tersebut memberikan batasan ruang lingkup jenis-jenis hak yang wajib dikelola oleh lembaga manajemen kolektif. Sebagai rujukan yang dapat digunakan adalah pengaturan komprehensif seperti di Jerman. Jenis-jenis hak yang wajib dikelola oleh lembaga manajemen kolektif, yaitu remuneration for cable retransmission, resale right for artistic works, remuneration for rental and lending of works, remuneration for the 
reproduction and distribution of works for the benefit of disabled persons, remuneration for the reproduction and distribution of broadcast commentaries and individual articles from newspapers, dan remuneration for the making available to the public of works for the purpose of teaching and research.

2. Untuk menghindari penyalahgunaan posisi dominan atau monopolistik, lembaga manajemen kolektif di Indonesia perlu diatur dalam kerangka regulasi yang komprehensif. Kerangka regulasi bagi lembaga manajemen kolektif mengatur hal-hal antara lain mengenai pendirian, hubungan lembaga secara internal maupun dengan anggotanya, dan secara eksternal dengan pengguna, aspek transparansi dan akuntabilitas, skema tarif dan lisensi, pendistribusian hasil pendapatan dan pencegahan penyalahgunaan posisi monopolistik.

3. Status sebagai lembaga nirlaba sebagaimana diamanatkan oleh UU Hak Cipta 2014 seharusnya memberikan dorongan kepada lembaga manajemen kolektif untuk menjalankan fungsi sosial dan budaya. Fungsi sosial dan budaya tersebut harus diatur dalam kerangka peraturan perundang-undangan yang memaksa, seperti kewajiban untuk menyisihkan sebagian pendapatan dari penarikan royalti yang digunakan bagi pengembangan seni dan budaya. Bahkan, untuk mengatasi kesejahteraan para pencipta, lembaga manajemen kolektif diwajibkan untuk dana pensiun bagi para anggotanya, terutama pencipta individu. Kemudian, aspek transparansi dan akuntabilitas lembaga manajemen kolektif di Indonesia perlu diatur dalam kerangka reguasi yang komprehensif, dimana setiap anggota mempunyai hak informasi memadai dan lembaga manajemen kolektif mempunyai kewajiban untuk menyampaikan laporan kepada masyarakat dan/atau pemerintah sebagai lembaga pengawas. Kerangka regulasi yang ada belum secara rinci mengatur substansi laporan. Substansi laporan dapat merujuk standar di negara-negara Eropa dimana laporan lembaga manajemen kolektif harus memuat hal-hal sebagai berikut: operasional lembaga, aturan organisasi, perijinan operasional, aturan pendistribusian, tarif, repertoire, daftar dan detil para pengurus serta laporan publik dan resolusi. 


\section{DAFTAR PUSTAKA}

Agung Damarsasongko, Ketentuan Tentang Lembaga Manajemen Kolektif Dalam Undang-Undang No. 28 Tahun 2014 tentang Hak Cipta, Meida HKI, Direktorat Jenderal Kekayaan Intelektual, Kementerian Hukum dan HAM.

CISAC, The Importance of Collective Management, International Confederation of Societies of Authors and Composers.

Darji Darmodiharjo. Shidarta, Pokok Pokok Filsafat Hukum, PT. Gramedia Pustaka Utama, Jakarta, 2004.

Engelbrekt, Antonina Bakardjieva, Toward Network Governance of Collective Management Organisations in Europe: The Problem of Institutional Diversity, in Karnell et al. (Ed.), Liber Amicorum Jan Rosén, Eddy, Oktober, 2016.

Ficsor, Mihaly, Collective Management Of Copyright And Related Rights, WIPO, 2002.

Hviid Morten, Simone Schroff, \& John Street, Regulating Collective Management Organisations by Competition: An Incomplete Answer to the Licensing Problem?, 7 JIPITEC 256 para 1, 2016.

Ka Lin, Cultural Traditions and the Scandinavian Social Policy Model, Social Policy \& Administration, Vol. 39, No.7, Desember, 2005.

KEA-European Affairs, The Collective Management of Rights in Europe. The Quest for Efficiency, Juli, 2006.

Logos, Transparansi, Akuntabilitas, dan Kontrol Dalam Pembiayaan Pertahanan (Problem dan Rekomendasi), 2003.

Mardiasmo,Akuntansi Sektor Publik, 2004, Penerbit Andi.

Salamon, L. M., \& Anheier, H. K. (ed), Defining the Non-profit Sector: A Cross-National Analysis, Manchester University Press, Manchester, 1997. 
Sherwood, Robert M., Intellectual Property and Economic Development, Alexandria, Virginia, 1990.

World Intellectual Property Organization, Collective Management of Copyright and Related Right, WIPO Publication, No. L450CM/E. 